\title{
A Research on Disneyland at Home and Abroad
}

\author{
Renxian Fan ${ }^{1, \dagger}$, Zeyu $\mathrm{Qu}^{2, \dagger}$, Ran $\mathrm{Wen}^{3, *, \dagger}$ \\ ${ }^{1}$ Hefei No.1 High School, 230091, Hefei China \\ ${ }^{2}$ Major 11B RDFZ King's College School, Hangzhou, 310007, Hangzhou China \\ ${ }^{3}$ Xiamen Haicang Experimental School, 361026, Xiamen, China \\ ${ }^{*}$ Corresponding author. Email: guanghua.ren@gecacdemy.cn \\ These authors contributed equally.
}

\begin{abstract}
The popularity of Disneyland has been upswing day by day. Analysis and studies of Disneyland become more and more significant. This essay discusses the overviews of national and foreign Disneyland conditions by using the document study method. For national Disneyland, we focus on the sinicization, the mode of management, marketing strategies, and inspirations from them; for foreign Disneyland, we investigate the history of its development, features, connotations, culture, and localization and experience of management. Through our research on Disneyland worldwide, we can find that Disneyland has taken a lot of action, including localization, marketing planning, and so on, which can ensure its success. Make the theoretical knowledge continue to enrich and develop, learn more management strategies and knowledge, to calmly cope with the future in the practical management problems and challenges.
\end{abstract}

Keywords: Disneyland, localization, sinicization, marketing planning

\section{INTRODUCTION}

In 1955, Walt Disney founded the first Disneyland worldwide in Los Angeles, California, USA. And then, Walt Disney World Resort Orlando was set up in 1971. Successive, in 1983, 1992, 2005, 2016, Tokyo Disneyland Resort, Disneyland Resort Paris, Hong Kong Disneyland Resort, and Shang Hai Disney Resort were founded respectively [1]. Under Disneyland's successful position of itself, there is 21.592 billion dollars income for Disneyland Resort [2]. Disneyland becomes so important because, with its rapid development, it shows the economic effects of culture and entertainment, which has aroused wide attention in society. After 2005, Hong Kong, China Disneyland officially opened, and Disneyland in Shang Hai was also built in 2016, which led to an upsurge in research into Disneyland in China. As a result, there are a lot of domestic and foreign perspectives of concern and research. So, this is why we choose to study the development of Disneyland in domestic and foreign countries.

Based on the background information and current situation mentioned above, it is easy for the public to find that nowadays, Disneyland is so attractive that plenty of people are trying to explore more from it: more and more tourists are involved in traveling and having great fun there; more and more scholars have become interested in the development of Disneyland both from home and abroad; a great deal of researches and studies have been done from various aspects. With the development of society and economy, Disneyland becomes a popular topic among individuals and has emerged on many periodicals, newspapers, and academic platforms. People hope to find something useful and novel from the mysterious Disneyland. However, there are still many puzzles that we have to think about, especially in terms of its marketing strategies and management. What are the differences that we can tell between Chinese Disneyland and foreign ones? What causes those differences? If we accomplish it successfully, what kind of aspects of our country and who will benefit? To help establish a basis for further studies and fulfill future goals, we decided to delve into this study from the native Disneyland and foreign ones. After figuring those questions out, immediate progress in these fields will be shown up apparently.

Through a series of journals and individual report analyses, we can derive Disney's management model and marketing strategy through a large number of data reports. Disney does not feel naive while helping adults 
feel innocence. Whether it is domestic or foreign, Disney has a unique marketing model. Especially in China, Disney has launched similar activities such as uploading relevant videos to the Internet to win tickets, thereby helping Disney to promote it even more. Disney uses the most convenient and efficient advertising method to attract people from all over the country through powerful online self-media. Combined with the local cultural characteristics, the Disney parks worldwide are different from each other because of some details. Disney's management pattern is also unique. It upholds the SCSE idea, which allows Disney tourists to experience high-quality services, and has also established a reward and punishment system for employees so that every employee can have the opportunity to get a promotion and salary increase; Disney is willing to accept the opinions and suggestions of every employee as well. As one of the most famous theme parks globally, Disney's creativity can provide a reference for many domestic theme parks. China's theme parks focus too much on ticket sales and the pursuit of exciting amusement projects, thus forgetting the staff's service attitude and tourists' play experience. However, Disney has produced a large number of its own industrial chain and launched countless peripherals, making more tourists willing to go to Disney for the second time.

\section{A REVIEW ON THE DEVELOPMENT OF DISNEYLAND IN CHINA}

After introducing our research questions and ideas, we first conducted a study based on the domestic Disneyland. It can be divided into these parts: sinicization, management mode, marketing strategies, and the reference and enlightenment.

\subsection{An Overview of The Sinicization of Disneyland}

The sinicization of Disneyland, as the name suggests, is how Disney Park adapts to the Chinese Market step by step, including culture, food, and so on, which is about regional as we found that the researches about the sinicization of Disneyland have been influential in the field. This is because China's market becomes an important part of all around the world, so Disney company needs to hold this significant opportunity. Based on the large-scale CNKI and other databases, we have found many analyses, research, and paper about this. By investigating many writers' ideas, we can conclude in two aspects--the sinicization of environmental facilities and service products.

One aspect is that Disneyland, through improving surrounding and internal facilities to better complete sinicization. Zhanlu Yin, Wenxuan Sun, and Ziqi Qu [3] take Shanghai Disneyland as an example. They point out that to convenience visitors to come to Disneyland, they set up building 11 of the subway as Disney Station. Also, in Disneyland, they employ Shanghai locals to be employees, which occupy 98\%. Besides employees, Zhanlu Yin, Wenxuan Sun, and Ziqi Q found that Disneyland adds some Chinese elements to their Fantastic Fairy Tale Castle, such as Xiangyun, peony, and lotus. This makes the Chinese more interested because these are their own culture, so they will feel a sense of belonging. Especially during the Chinese Festival, such as Spring Festival, Shanghai Disneyland will combine Chinese culture and Micky elements to create red and yellow lanterns and beaming Spring Festival couplets to construct an environment of the home. Another author from the Internet gives a point of view [4] that the park's local image was enhanced through executive interviews and localized events. Also, during the opening eve celebration, "Chinese composer Tan Dun, known for his film scores for Crouching Tiger, Hidden Dragon, was invited to conduct the Shanghai Symphony Orchestra in performing his original composition for Shanghai Disneyland titled 'Igniting the Magical Dream,' which blends Chinese and Western music motifs along with iconic Disney music [4].” And we found that an elderly male was playing Erhu (Chinese violin) with a young girl and a choir of 800 numbers, highlighting the fusion of Chinese and Western culture. The finding of these studies can be understood as Disneyland want their consumers to feel more comfortable when they spend their time in it. So it pays more attention to the setting of Disneyland's environment, employees, and so on. There will be more and more local elements present to Disneyland in different places in the longer term.

The other aspect is about the sinicization of service products. Firstly, to be in line with the eating habits of the local people, Shanghai Disneyland build a special place to concentrate Chinese restaurant, named Manyueshifu. Just like Geyao Fu said [5], they cover Sichuan, Hunan, Guangdong, and other traditional Chinese cuisines. The local people love this down-to-earth service. Second, Geyao Fu points out that during the garden show, Disneyland also makes some adjustments. For example, Donald Duck will do Tai Chi with its friends Chip'n Dale. Also, the employees here will wear Chinese-style clothing, such as plum blossoms, orchids, bamboo, and chrysanthemum. In this way, they can promote Chinese culture. Besides, in the Lion King's performance, Disneyland translates original English into Chinese, and most of the actors and actresses are Chinese. Extraordinary, they incorporate elements of Peking Opera and Sun Wokong, elevating the perception of the audience. 


\subsection{An Overview of The Management Mode of Disneyland}

As one of the most famous theme parks globally, Disney entered the Chinese mainland market in 2016. Jiayi Zhu pointed out that Shanghai Disney received more than 4 million visitors in the four months after its opening [6]. Disney's success is inseparable from Disney's unique management pattern: Disney has formulated separate management methods for employees and visitors based on local culture. Just like Yingchengyi Li said, in the management of employees, Disney adheres to the concept of "SCSE"-Safety, Courtesy, Show, and Efficiency. Every employee who enters Disney needs to undergo professional training, have a deep understanding of Disney's culture, and plan the words and deeds of each employee to ensure that visitors can feel the management philosophy of Disney's courteous hospitality. Shanghai Disney hired a large number of local talents and employees in Shanghai and allowed each employee to be promoted so that each employee has a different goal [7]. When Disney recruits employees, it does not value the employees' achievements and family background. They pay more attention to the mind and hearts of the candidates. Every employee of Disneyland can put forward new innovations and ideas, and more and more wonderful ideas will let every employee participate in building a better Disneyland, said Sidun Zhang [8]. What's even more shocking is that when working overtime is commonplace in today's society, Disney respects every employee's time and will not take them every minute and every second [9]. Second, the management of tourists. Disneyland does not allow visitors to bring any food into the park, but Disneyland provides plenty of international restaurants. Disneyland provides not only western food from all over the world but also Chinese food of various cuisines. Although, just like Geyao Fu said, Disney does not allow any food to enter, the multi-style restaurants allow visitors to have more choices [5].

\subsection{An Overview of Marketing Strategies and Modes of Disneyland}

Shanghai Disneyland has attracted a large number of tourists in a short period. Their marketing methods must be very elegant and uniq ue. On an opening day, Disney invited many influential celebrities in China and conducted live broadcasts throughout the whole process, attracting hundreds of thousands of viewers, which brought a lot of influence. Some celebrities posted photos of their games at Disney on the Internet, attracting more fans went to play. And with the help of the increasingly powerful Internet, Disney invited many internet celebrities to come to play and experience, attracting a large number of fans in just a few days. In addition to inviting some celebrities,
Shanghai Disney launched a publicity advertisement on the Internet, inviting people from all over the network to participate in the event, and playing games to win Disney tickets. Or take photos to win likes to get tickets, written by Yihan Wang [10]. Disney's offline promotion is to form an industrial chain. Starting with movies and toys, it attracts innocent children and welcomes adults with childlike innocence. Disney is full of Disney animation characters in every corner of the park, so Disney uses its offline industry chain to attract tourists to come and play [11].

\subsection{Summary on The Reference and Enlightenment of Disneyland to China's Development}

As one of the top theme parks, Disneyland can inspire many theme parks in China. Most of the domestic theme parks are too focused on the revenue of tickets, so all management styles and publicity methods are aimed at maximizing ticket sales, thus forgetting the real thoughts of tourists and thinking that they are pursuing the excitement of amusement, so that people who play only stay in one group of people [12]. However, Yanjin Jiang expressed that Disney has formed its own huge industrial chain so that tickets, toys, and other products can bring huge benefits. China's theme parks should form their own unique industrial chain, or a series of products, so that tourists can have more memory points, thus bringing more customers, and that more tourists are willing to play a second time [13]. In addition, Disney's performances are also the objects of learning in domestic theme parks. Disney has many daily performances, and Disney's performances, merchandise, and toys are all related, not a few scattered items. Disney can use the performance to play the role of secondary advertise and ultimately achieve the purpose of attracting tourists to buy commemorative goods [14]. In addition, Travel agencies play an intermediary role in tourism, undertaking tourism product design, organization and coordination, information transmission and so on. The completion of Shanghai Disneyland, which brings a huge source of tourists, will greatly promote the Yangtze River Delta tourism and hotel industry income. It is estimated that the Shanghai Disneyland will bring about 30 million tourists to Shanghai every year. If each tourist stays in the Yangtze River Delta area for 3 days and the average bed is 150 yuan, it is estimated that the completion of the Shanghai Disneyland will bring about 10 billion yuan of revenue to the hotels in the Yangtze River Delta area every year. [15] 


\section{A REVIEW OF FOREIGN RESEARCH ON THE DEVELOPMENT OF DISNEYLAND}

Scholars have not only studied Disneyland in China, but they have also put a lot of effort into Disneyland abroad. Some of them did studies of Disneyland in China. Also, some authors compare Disneyland all around the world. The following parts focus on development history, the features, connotation and ideology, Culture and Localization, and Management Experience.

\subsection{An Overview of The Development History of Disneyland}

Disneyland has become the most well-known amusement park all over the world. Many researchers are curious how it can be successful now. We have investigated the basic information of Disneyland's success. We categorize this part into three aspects: the development of Disneyland, its current achievements, and future speculation for it.

Walter Disney, the leader of this company, got the inspiration from the experience of visiting an amusement park in Kansas City with his daughter Diane, which has been mentioned in Mittermeier, Sabrina's book called A Cultural History of the Disneyland Theme Parks [16]. He found that there was no amusement park allowing both adults and children to have fun. Thus, he designed his own park and tried a lot of ways to get enough money. Eventually, he succeeded. In 1955, the new year greeted the coming of the first Disneyland in California.

The story of expanding to the world later started in Los Angeles. As time passed by, Walt Disney has established five more Disneyland world-widely. It's worth mentioning that Disney World in California made $\$ 195$ million in profit in just ten years. Although Disneyland in Paris made a great loss, the profits from the other Disneyland offset the loss and then still had a great surplus. The number of visitors is shocking as well. "The six parks accounted for $55 \%$ of the total number of visitors in North America, and Disney Group owns the top five theme parks in North America, and six of the top 20 are Disney theme parks." [17] More and more people are willing to visit Disneyland, shown in the figure [18].

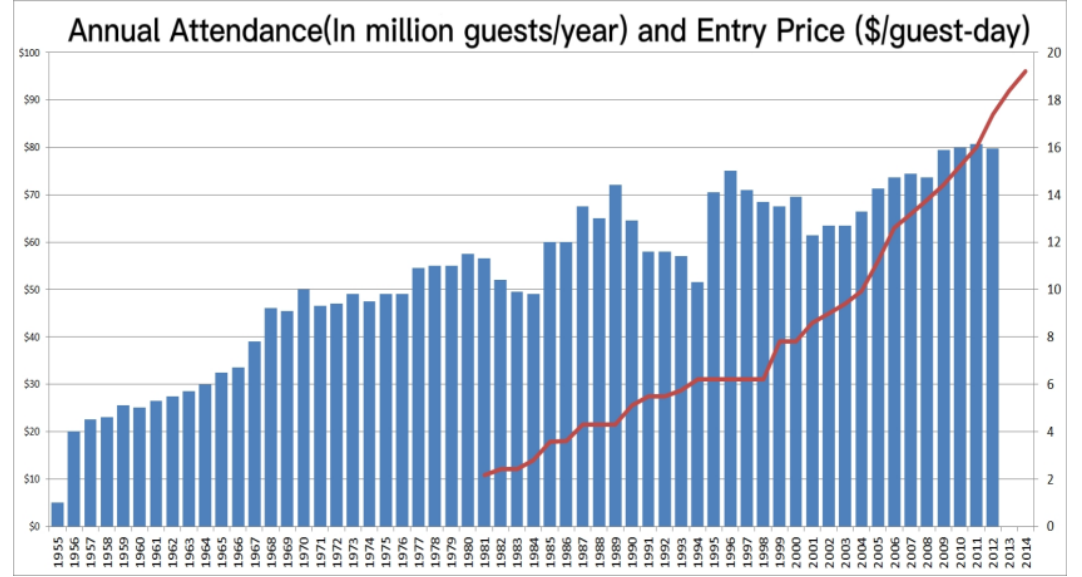

Figure 1 Annual Attendance (In million guests/year) and Entry Price(\$/guest-day) [19]

We anticipate that the Walt Disney Company might select a new location in Europe for the 7th Disneyland in the world. It also might be able to contribute the Walt Disney's become the greatest entertainment company in the world.

On this basis, we conclude that Disneyland plays a significant role in gaining benefits for the Walt Disney Company and has got a great place in the worldwide field of amusement parks.

\subsection{An Overview of The Features of Disneyland}

Further exploring the success of Disneyland, there must be something unique for it to stand out among the countless number of amusement parks around the world. After doing researches, we find that Disneyland has stood out for three reasons below: a large amount of IPs, its cultural value, and its complete industrial chain.

Almost everyone in the world can call some of the popular characters of Disney culture, such as Snow White, Spiderman, and Mickey Mouse. Wiersma, Beth Ann mentioned that these well-known IP names have undoubtedly become the largest advantage, compared to other amusement parks, which all lack many of these worldwide famous representative characters. To make maximum use of IPs, many retail stores sell derivatives. This helps make the profits into an economic peak.

The theme culture of Disneyland still has something outstanding, which means the spirits and the qualities that the characters express are so attractive for people all over the world that Disneyland can be considered as the 
greatest wonderland. For example, according to Dam Lisbet Rosa's analysis, Snow White, a beautiful but cruelly treated girl, keeps being tolerant to everyone, including her Evil Queen and the seven dwarfs. This kind of tolerance to all the negative emotions is considered a "masochistic heroine" by Ussher [20]. But in the later series of movies, Snow gains privilege "sweetness" by using her tolerance, which helps her survive Huntsman. Every time when Snow encounters risks, she can still be safe as last. Such a setting matches the perfect world of fairy tales and does protect every child's wonderful dreams.

Also, older Disney films do not present a conventional family pattern for audiences, but they represent some special ones, such as the lack of one of the parents. Such backgrounds for each character are totally opposite to the contemporary families, which are always parents with their children [21]. This can be considered as a great thought of stories with innovations.

The industrial chain of Disney is unique as well. Creating its own brand characters, purchasing some more IP sand then developing various products, such as movies, amusement parks, even the center of learning English, Walt Disney paid a lot of effort into his company. Such irreplaceable creativity definitely becomes the prerequisite of succeeding among all entertainment companies.

In conclusion, Disneyland has great advantages in terms of popular and unique IPs, valuable meanings of characters, and the complete industrial chain.

\subsection{An Overview of Disneyland's Connotation and Ideology}

What also contributes to the Walt Disney Company's success must be its connotations and ideology. We divided the contents into the following two parts:

Disneyland paints all its outcomes in fairy tales color, which leads people of all ages to be able to settle down and take a breath. It has become a symbol standing for the magic and dreamlike wonderland and a shelter of reality and complication.

Aiming to create a "dream world" appeals to people to form a kind of attitude called "yuttarism" explained by Mary Yoko Brannen, [22] which means to pay more attention to relaxation and comfort, such an attitude does fit in the current consumer trend. The Dentsu Advertising Agency announced that consumers are "seeking quality in this world rich with things, [and] are starting to pursue affluence of the mind, time and environment." [23]

The qualities and the spirits conveyed by the leaders of the Walt Disney Company also played an important role. Walter is a visionary with great creativity and talents. At first, he participated in the design cartoons just because of his interests. Fortunately, according to Mittermeier, Sabrina, Walter's first most famous creation, Mickey Mouse, came out, and later it was introduced to the world through Steamboat Willie in 1928 [24]. Then he managed to helm the first full-length animated feature film, Snow White and the Seven Dwarfs, in 1937. what is more, his consistency and highly efficient actions gave birth to the first Disneyland. This accomplishment all came from his strong, willing, and colorful imaginations. One of Walter's successors, Robert Allen Iger, can also be a great leader. He was so capable of decision-making and insight that he oversaw the acquisitions of Pixar in 2006 for $\$ 7.4$ billion, Marvel Entertainment in 2009 for $\$ 4$ billion, Lucasfilm in 2012 for $\$ 4.06$ billion, and the entertainment assets of $21 \mathrm{st}$ Century Fox in 2019 for $\$ 71.3$ billion. The public admires his quality of making correct decisions.

In a word, a company's success cannot be without the precious values from not only its intentional connotation but also the great wise guidance of its leaders.

\subsection{An Overview of The Culture and Localization of Disneyland}

The localization of Disneyland is a discussion of how Disneyland operates in different countries and regions, different from the specific regions emphasized by sinification. There are various and large-scale researches about the culture and the localization of Disneyland. Different writers express their different views, whether from domestic or foreign, they analyze almost all Disneyland worldwide. Based on Google scholar and so on, we can make a categorization. Advertising localization, product localization, and culture localization, respectively.

Firstly, it is about advertising localization. According to Micky Lee and Anthony Y.H. Fung's opinions [25], we can understand that at Hong Kong Disneyland, they make some difference in their advertising to attract more tourists from mainland China. In the original advertisement, some people always dress more casually, such as denim jeans and sneakers. However, the advertisement for Chinese is different. Micky Lee and Anthony Y.H. Fung point out that there is a girl dress up like a princess and a boy dress up in a sweater and a button-down shirt. This is because people in mainland China often wear formal suits and leather shoes for men, and women prefer high heels. They think that it is a really good chance for them to experience life in the west. Dressing like these can make them feel like they are here. Therefore, Micky Lee and Anthony Y.H. Fung focus on the difference between daily dress-up and people's views on new things in different countries. They know that Disneyland can attract more local visitors by making advertisements that suit local people. 
Second, Micky Lee and Anthony Y.H. Fung discuss product localization. From Hong Kong Disneyland, they point out that Disneyland translates the signs to English and traditional Chinese characters for the locals. Also, employees here need to be fluent in conversational English, Cantonese, and Mandarin. Disneyland considers the preference of Chinese consumers, so they sell Disney jewelry in 24-carat golds at Main Street USA. The reason is that gold is a precious metal that is a perennial favorite of the Chinese. This also happens at Tokyo Disneyland. Micky Lee and Anthony Y.H. Fung mention that there are a lot of games, such as Stitch Encounter, and live shows like The Golden Mickeys are featured in Japanese only. Also, the local restaurant provides only Japanese menus. In addition, it is found by Micky Lee and Anthony Y.H. Fung that Disneyland changes Sleeping Beauty Castle into Cinderella Castle since the Japanese are more easily connect Cinderella with Disney. All in all, we can conclude that Disneyland translates the language into the local language to convenience the people here. They also do research on the taste and culture of Hong Kong and Japan. In this way, there will be more people who prefer to play in Disneyland.

Moreover, it is mentioned by Jonathan Matusitz [26] that Disneyland localizes through adapt to the local visitors' customs, in other words, accommodate to the local culture. To be more specific, Micky Lee and Anthony Y.H. Fung supplement that in Hong Kong Disneyland. It will make others remind "uncivilized" behavior of mainland Chinese, so they don't allow people to sit on the floor. By contrast, because of the custom of the Japanese, Tokyo Disneyland permits them to bring a blanket and sit on the floor to enjoy the parades. Also, in Tokyo Disneyland, unlike employees in America, they put their last name and their first name on their name tags. All these things are according to different countries' cultures to make difference adjustment.

\subsection{Summary of Management Experience of Disneyland}

From Google scholar, we found amounts of paper and periodical discuss different aspects of Disneyland's administration and management. As we all know, Disneyland won't have such success if they do not have this set of management. But in this part of the topic, we will focus on the management of the cross-culture strategy.

From Gao Rui and Ph.D. Jerome Dumetz's ideas [27], we found that the importance for Disneyland to make a cross-culture management. In the Paris Disneyland example, it is clear to see that after considering local culture, Disneyland Resort Paris gradually from a loss to a profit.
Disneyland did not understand the cultural influence in the past, so when they manage the Paris Disneyland, they do not consider the style of buildings and European consumption habits. Gao Rui and Ph.D. Jerome Dumetz points out that employees in Paris Disneyland are supposed to speak English. This action brings a large scale of inconvenience. Also, they incorrectly judge the length of time people come to visit. From an analysis [28], researchers found that most people stay here only one day or two days, four or five days less than expected. As a result, Paris Disneyland faces a big loss because of the low passenger flow volume. Gao Rui and Ph.D. Jerome Dumetz claims that to better achieve cross-culture management, Disneyland needs to follow three steps: first of all, it has to identify cultural differences; the second step is to train the culture sensitivity; third, it should build common values and corporate culture. The other analysis claims that it is also very important for Disney to recognize that they need to rationalize allocating resources and staff.

By realizing its own problems, Gao Rui and Ph.D. Jerome Dumetz mentions that Paris Disneyland is a good illustration of these three steps:

In the beginning, Disneyland changes its name in Paris from "Euro Disney Resort" to "Disneyland Paris", to catch a part of the French culture into the band identity of the park.

Then, their working language is no longer just English. Disneyland also adds French. In this way, consumers will feel more convenience.

Third, Disneyland Paris had experienced from American management to full French management. This action enables them to be familiar with local culture and make some adjustments to the building styles and food in Disneyland. Moreover, to adapt to Europeans' eating habits, the restaurants in Paris Disneyland provide alcoholic drinks to visitors. Because wine is an indispensable part of life and meal at their local culture without it is imperfect. Through this cross-culture management, Disneyland Paris makes a big profit. In summary, these materials argued the impact of cross-culture management on Paris Disneyland. Based on this result, we can know that Disneyland must understand the location it wants to build because this has a direct connection with the popularity of local residents. This can help them make a bigger profit.

In addition to the management of Disneyland, many resorts, including Disneyland, have bring benefits to local. First, they have led to the development of local tourism. Just like Dridea Catrinel Raluca and Strutzen Gina[29] say "theme parks are star players in the tourism industry, and play a special and important tole in generating tourism demand." They also give a definition of theme parks that a subset of visitor attractions. Dridea Catrinel Raluca and Strutzen Gina 
give an example in USA, where most of the theme park tends originated, that each year there are more than 200 million paid attendees. It is not hard to understand the significant of resorts. Also, PAWAN K. SHUKLA and A. A. ANSARI[30] point out that at Kutch region, the development of resorts helps in the direct and indirect employment to local people. To be more specific, more than $80 \%$ of those employed in the resort including the manager, receptionist, kitchen staff, drivers, especially in food preparation and serving jobs, including waiters and waitresses, fast food and counter workers and so on.

\section{CONCLUSION}

Through researching different topics, we have obtained a lot of information about Disneyland. We will review these studies by comparing Disneyland all around the world next.

\subsection{Research Comment}

The first is about the localization and sinicization in domestic and foreign Disneyland. Through studying so many papers and materials, we can find that wherever Disneyland is in the world, they try to adapt to the local culture. From this, we can recognize four common points between sinicization and localization. There are four aspects --- staff, food, language, and facilities. Firstly, to attract more local people, they hire local employees and ask them to speak the local language. Besides, Shanghai Disneyland covers Sichuan, Hunan, Guangdong, and other traditional Chinese cuisines by considering local taste. And Tokyo Disneyland provides Japanese menus. Third, they translate signs and performance into the local language. Moreover, they focus on adding local elements into Disneyland's buildings and so on. All this effort they put into realizing localization and sinicization.

The second is about the management of Disneyland. It is not difficult to find that the ultimate pursuit of detail management of Disneyland in the world is in the same line, which embodies the intimate and humanized concept contained in it everywhere. One detail is the toilet. Next to each project in the park, there are toilets consistent with the project's appearance, anti-skid floor tiles, colored wall tiles, not only beautiful shape but also no smell at all. "When there are many people, clean it all every half an hour; if there are not many people, you just clean it once to keep the toilet clean." Caring for people with disabilities, the first row of seats in the theater is clearly reserved for wheelchair guests, and other visitors start in the second row. Because there are barrier-free channels everywhere, you can see a lot of wheelchairs playing guests in the park. Also, Disneyland needs to focus on the management of cross-culture. Since adapting to the local culture can be more conducive for the company to attract tourists, which can help them achieve greater wealth.

The third is about the review of the situation in foreign Disneyland. It has developed step by step from an inspiring idea to current worldwide amusement parks. All its achievements can attribute to the unique industrial chain, popular IPs, and the cultural value behind every character. The connotations behind the whole Disney culture can be significant as well. Each IP can present a certain internal meaning, like the designers' view of current society and some appealing to a specific belief. Disneyland definitely provides the public a chance to keep light-hearted in such a wonderful shelter. All of those things are not seen in other amusement parks.

Forth is about the marketing planning of Chinese Disneyland. It is well known that Disneyland is very popular in China. Both adults and children want to have a play. But why can Disneyland be so popular? Disneyland provides tourists with sensory experience and emotional experience, integrating them into it, creating strong emotions, and using their brains to enhance knowledge. At the same time, related marketing, such as people think of Mickey Mouse Donald Duck, will think of Disneyland. At the same time, there is no playground like Disneyland in China, so people are curious and often pour into it. So it is because of the above points that Disneyland is so successful.

Fifth is about the enlightenment. In essence, Disneyland is a major brand and business field of Disney Company, a multinational media giant. The construction and operation, marketing, enterprise planning, and so on embody enterprise operation and management behavior. Disneyland's success is to adopt a diversified, situational, and experiential business strategy so that tourists can get a comprehensive and deep pleasure feeling. It will be very good to achieve the company's business purpose. The integration of management methods and strategies at home and abroad is actually to achieve the core value of Disneyland. This value is achieved through diversified business strategies. By integrating the internal and external resources of the enterprise, the business effect of the system function is greater than the sum of the elements, which provides more additional value for consumers. And in the service of a high division of labor, highly professional principles and when to meet the needs of tourists.

Sixth, we focus on the research methods. Both domestic and foreign Disney parks have used quantitative methods. Based on the fact that Disney already has six theme parks in the world, based on the sales volume of the first few parks, Disney can get enough experience from it and apply it to more Disney parks expand. 
Seventh is about the research paradigm. We can look at the resources from our research at both a macro and a micro level. At the macro level, we have already found some paper or periodical deal with the problem, such as an overview of the development history of Disneyland, the features of Disneyland and Disneyland's connotation and ideology, and so on. From a micro level, it is very successful for us to analyze some inner problems with Disneyland. To be more specific, we have explored how Disneyland is adept to the local culture and the marketing approach.

Eighth is about the object of study. As the most popular amusement park in the world, Disneyland wins a lot of public attention not only from the consumers but also from academic scholars. So far, nearly all aspects of Disneyland have been studied, ranging from its own value to some latest policies. The most severe problem of the Walt Disney Company is that fewer and fewer valuable IPs are created. The creativity of all companies in the entertainment field seems to become a common problem.

Finally, we also found that expect for Disneyland, other amusement parks can contribute to the local tourism development. They not only bring passenger flow volume, but also provide a lot of new careers to local people.

\subsection{Future Prospect}

Compared with other multinational and global companies, Disney has not acquired a large number of companies. As a result, although Disney appears to be very popular worldwide, Disney is not suitable for people of every age. Therefore, Disney should acquire or create more industrial chains to cater to people of every age group and apply them to Disneyland, so that theme parks can attract every visitor and become more global.

From a macro aspect, based on the materials we found, we realize a lack of research on Disneyland's future. Most of the papers and periodicals we found just focus on the problems Disneyland wants to solve or have already solved. It is hard to find material talking about Disneyland's potential problem or their future fate. Moreover, from a micro aspect, we think they can be a little bit more detailed. For example, on the management side, they can list a more touristy approach. What is that mean? They can focus on whether Disneyland has used a reasonable way of queuing will not make tourists feel so agitated to attract more tourists and make more money. There are many similar problems, and professionals can do more research.

We hope to see more accurate and professional research and studies that can dig into the inherent cause of this lack of creativity and give out some possible solutions.
Finally, we expect that our research can help other scholars' research on this aspect in the future, including Disneyland's localization, marketing planning, development history, and so on. In this way, our study will become more meaningful.

\section{REFERENCES}

[1] Available at:https://mbd.baidu.com/ma/s/okJXWFfV,accesse d 14 July 2021.

[2] Available at:http://wap.traveldaily.cn/article/133159,accessed 14 July 2021.

[3] Zhanlu Yin, Wenxuan Sun, Ziqi Qu.Analysis on the Development Strategy of "localization" of Disneyland --- Taking Shanghai Disneyland as an example[J].Tourism Overview(the second half of the month),2018(11):65-68.

[4] Available at:https://ebrary.net/152064/geography/hong_kong _disneyland,accessed 24 July 2021.

[5] Geyao Fu.Research on the development status and improvement strategies of Disney's Chinese localization marketing --- A case study of Shanghai Disneyland[J],China Management Informationization, October 2020(20):101-102. DOI: 10.3969/j.issn.1673 - 0194.2020.20.046

[6] Jiayi Zhu, P 2017, ' The marketing approach of Disney theme parks' CHINA CIRCULATION ECONOMY, no. 21, pp. 13-14. Available from: China Academic Journal Electronic Publishing House. [22 July 2021].

[7] Yingchengyi Li, P 2018, 'Analysis on the marketin g strategy of Disney theme parks__ Based on the perspective of the integration of global marketing and

localized marketing', Journal of Hubei University of Economics (Humanities and Social Science), Vol. 15, no. 10, pp. 68-70, 76. Ava ilable from: China Academic Journal Electronic Publishing House. [22 July 2021].

[8] Sidun Zhang, Qinlei Li, Yang Lou, P 2018, ‘ Research on Creative Management Methods of Tourism Enterprises-Taking Disney as an Example', JOURNAL OF QINNAN NORMAL UNIVERSITY FOR NATIONALITIES, Vol. 38, no. 4, pp. 75-80. Available from: China Academic Journal Electronic Publishing House. [22 July 2021].

[9] Xia Wu, Jinhua Huang, P 2019, ' Analysis of the reasons why Shanghai Disney won the Best 
Employer Award', CHINA CIRCULATION ECONOMY, no. 30, pp. 100-101. Available from: China Academic Journal Electronic Publishing House. [22 July 2021].

[10] Yihan Wang, P 2017, 'New Media Marketing Analysis of Shanghai Disneyland', MEDIA MARKETING, no. 13, pp. 69-70. Available from: China Academic Journal Electronic Publishing House. [22 July 2021].

[11] Wang Xu, P 2019, 'Practical Exploration of the International Route of Chinese Cultural Creativity__ On the experience of "Disney", Cultural Dialogue, no. 9, pp. 190-191, 194. Available from: China Academic Journal Electronic Publishing House. [22 July 2021].

[12] Xinye Wang, P 2010, 'Disney: From theme amusement park to consumer goods giant' Brand Marketing, pp. 52-54. Available from: China Academic Journal Electronic Publishing House. [22 July 2021].

[13] Yanqin Jiang, P 2014, 'The Enlightenment of the Development of Disneyland to China's Cultural Industry', Modern Education, no. 18, pp. 29- 31. Available from: China Academic Journal Electronic Publishing House. [22 July 2021].

[14] Xueli Yuan, P 2017, 'Enlightenment of Shanghai Disneyland to the creative industry', Modern Decoration(Theory), pp.225-226. Available from: China Academic Journal Electronic Publishing House. [22 July 2021].

[15] Available at:https://wenku.baidu.com/view/e147afa4f524ccbf f1218467.html[Accessed 27 August, 2021]

[16] S Mittermeier.A Cultural History of the Disneyland Theme Parks[M].Beijing:Middle Class Kingdoms,2020:16

[17] Blueyu Culture Development Co., Ltd. (2018). Brief introduction to the development history of Disneyland and its six major parks - Theme park planning and design, [online] Available at:http://www.lanyuwenhua.com/news_detail_1246 .html [Accessed 22 July, 2021]

[18] Aerotheque,(2011). Annual Disneyland Park Attendance, [online] Available at:https://commons.wikimedia.org/wiki/File:Annua 1_Disneyland_Park_Attendance.png[Accessed 22 July, 2021]
[19] Available at:https://upload.wikimedia.org/wikipedia/common s/b/be/Annual_Disneyland_Park_Attendance.png [Accessed 22 July, 2021]

[20] Lisbet Rosa Dam.Fairy Tale Femininities: A Discourse Analysis of Snow White Films 1916-2012[M].Victoria University of Wellington,2014:41-42

[21] Beth A. Wiersma.The Gendered World of Disney: A Content Analysis of Gender Themes in Full-length Animated Disney Feature Films[M].South Dakota State University,2000:116-117

[22] [23] Mary Yoko Brannen."BWANA MICKEY”: CONSTRUCTING CULTURAL CONSUMPTION AT TOKYO DISNEYLAND[M].Durham:Duke University Press, 1993:2

[24] S Mittermeier.A Cultural History of the Disneyland Theme Parks[M].Beijing:Middle Class Kingdoms,2020:15-16

[25] Anthony Y.H. Fung,Asian Popular Culture[M].London:Routledge,2013:42-58.

[26] Jonathan Matusitz,Disney's successful adaptation in Hong Kong:A glocalization perspective[J],Asia Pacific Journal of Management,28 October 2009(11):667-681

[27] Gao Rui and PhD Jerome Dumetz,Cross-culture management analysis Disneyland Paris[J].ЧЕЛОВЕЧЕСКИЙ КАПИТАЛ И ПРОФЕССИОНАЛЬНОЕ ОБРАЗОВАНИЕ,2019:109-112.

[28] Available at:https://bbs.binus.ac.id/ibm/2017/06/case-study-d isney-in-france-for-cross-culture-management/[Acc essed 25 July, 2021]

[29] Dridea Catrinel Raluca and Strutzen Gina,THEME PARK - THE MAIN CONCEPT OF TOURISM INDUSTRY DEVELOPMENT[J],Annals of the University of Oradea, Economic Science Series, 2008(Vol. 17, Issue 2):641-646

[30] PAWAN K. SHUKLA and A. A. ANSARI,ROLE OF TOURISM IN EMPLOYMENT GENERATION IN GUJARAT: A GEOGRAPHIC ASSESSMENT[J],International Journal of Research in Humanities, Art and Literature,2013(Vol. 1, Issue 2):1-8. 